\title{
Anti-HER3 monoclonal antibody exerts antitumor activity in a mouse model of colorectal adenocarcinoma
}

\author{
TEIZO ASANO $^{1 *}$, TOMOKAZU OHISHI $^{2 *}$, JUNKO TAKEI $^{1,3}$, TAKURO NAKAMURA $^{1}$, \\ REN NANAMIYA ${ }^{1}$, HIDEKI HOSONO ${ }^{1}$, TOMOHIRO TANAKA ${ }^{1}$, MASATO SANO ${ }^{1}$, \\ HIROYUKI HARADA ${ }^{3}$, MANABU KAWADA $^{2}$, MIKA K. KANEKO $^{1}$ and YUKINARI KATO ${ }^{1,4}$ \\ ${ }^{1}$ Department of Antibody Drug Development, Tohoku University Graduate School of Medicine, Sendai, \\ Miyagi 980-8575; ${ }^{2}$ Institute of Microbial Chemistry (BIKAKEN), Numazu, Microbial Chemistry Research Foundation, \\ Numazu-shi, Shizuoka 410-0301; ${ }^{3}$ Department of Oral and Maxillofacial Surgery, Graduate School of \\ Medical and Dental Sciences, Tokyo Medical and Dental University, Bunkyo-ku, Tokyo 113-8510; \\ ${ }^{4}$ Department of Molecular Pharmacology, Tohoku University Graduate School of Medicine, Sendai, Miyagi 980-8575, Japan
}

Received March 2, 2021; Accepted May 21, 2021

DOI: 10.3892/or.2021.8124

\begin{abstract}
HER3 belongs to the epidermal growth factor receptor (EGFR) family and is known to form an active heterodimer with other three family members EGFR, HER2, and HER4. HER3 is overexpressed in lung, breast, colon, prostate, and gastric cancers. In the present study, we developed and validated an anti-HER3 monoclonal antibody (mAb), $\mathrm{H}_{3} \mathrm{Mab}-17\left(\mathrm{IgG}_{2 \mathrm{a}}\right.$, kappa), by immunizing mice with HER3-overexpressed CHO-K1 cells (CHO/HER3). $\mathrm{H}_{3} \mathrm{Mab}-17$ was found to react specifically with endogenous HER3 in colorectal carcinoma cell lines, using flow cytometry. The $K_{\mathrm{D}}$ for $\mathrm{H}_{3} \mathrm{Mab}-17$ in $\mathrm{CHO} / \mathrm{HER} 3$ and Caco-2 (a colon cancer cell line) were determined to be $3.0 \times 10^{-9} \mathrm{M}$ and $1.5 \times 10^{-9} \mathrm{M}$ via flow cytometry, respectively, suggesting high binding affinity of $\mathrm{H}_{3} \mathrm{Mab}-17$ to HER3. Then, we assessed the $\mathrm{H}_{3} \mathrm{Mab}-17$ antibody-dependent cellular cytotoxicity (ADCC) and complement-dependent cytotoxicity (CDC) against Caco-2, and evaluated its antitumor capacity in a Caco-2 xenograft model. In vitro experiments
\end{abstract}

Correspondence to: Professor Yukinari Kato, Department of Molecular Pharmacology, Tohoku University Graduate School of Medicine, 2-1 Seiryo-machi, Aoba-ku, Sendai, Miyagi 980-8575, Japan

E-mail: yukinarikato@med.tohoku.ac.jp

${ }^{*}$ Contributed equally

Abbreviations: ADC, antibody-drug conjugate; ADCC, antibody-dependent cellular cytotoxicity; BSA, bovine serum albumin; CBIS, Cell-Based Immunization and Screening; CDC, complement-dependent cytotoxicity; DMEM, Dulbecco's modified Eagle's medium; EDTA, ethylenediaminetetraacetic acid; FBS, fetal bovine serum; mAb, monoclonal antibody; PBS, phosphate-buffered saline; SEM, standard error of the mean

Key words: HER3, monoclonal antibody, antibody-dependent cellular cytotoxicity, complement-dependent cytotoxicity, antitumor activity, colorectal cancer revealed $\mathrm{H}_{3} \mathrm{Mab}-17$ had strongly induced both $\mathrm{ADCC}$ and $\mathrm{CDC}$ against Caco-2 cells. In vivo experiments on Caco-2 xenografts revealed that $\mathrm{H}_{3} \mathrm{Mab}-17$ treatment significantly reduced tumor growth compared with the control mouse IgG. These data indicated that $\mathrm{H}_{3} \mathrm{Mab}-17$ could be a promising treatment option for HER3-expressing colon cancers.

\section{Introduction}

The epidermal growth factor receptor (EGFR) family, also known as HER or ErbB, has a tyrosine kinase domain in its intracellular region (1). The EGFR family transduces extracellular to intracellular signals through the activation of tyrosine kinase domain (1). By binding to the ligand, the extracellular domain promotes the formation of homodimers or heterodimers between the EGFR family receptors $(2,3)$. This dimerization is essential for the activation of the tyrosine kinase domain and intracellular signaling pathways such as Ras/MAPK, PI3K/Akt, and JAK/STAT (4,5).

The EGFR family consists of four members [EGFR (HER1, ErbB1), HER2 (ErbB2), HER3 (ErbB3), and HER4 (ErbB4)] and each member has different ligands: EGFR binds to seven ligands such as EGF, TGF- $\alpha$, and epigen; HER3 binds to neuregulin1 and neuregulin2; HER4 binds to seven ligands such as heparin binding-EGF, betacellulin, and epiregulin. In contrast, there is no ligand for HER2 (6,7). Although HER3 has a tyrosine kinase domain, its kinase activity is impaired $(8,9)$. Therefore, transphosphorylation by other members of the EGFR family is required to activate HER3. HER3 can form an active heterodimer with the other three members of the EGFR family $(2,10-13)$.

The EGFR family plays an essential role in regulating cell growth and in the differentiation, proliferation, and survival of normal cells. Insufficient EGFR signaling is associated with Alzheimer's disease and multiple sclerosis (14), while the overexpression of EGFR family is associated with the development of tumors (15-17). The EGFR family has been found to be overexpressed in many cancers as below: EGFR in breast, non-small 
cell lung, and prostate cancers (18); HER2 in breast, colon, lung, and pancreatic cancers (18); HER3 in lung, breast, colon, prostate, and stomach cancers $(2,19)$; HER4 in non-small cell lung, and ovarian cancers $(20,21)$. Therefore, the EGFR family is thought to be a valid target for candidates in cancer therapy.

High expression of HER 3 is thought to be an established negative prognostic factor in several solid tumors including colorectal cancer $(22,23)$. Metastatic colorectal cancer is one of the most aggressive tumors, associated with high mortality rates worldwide (24). In a previous study, $79 \%$ of primary tumors were found to present a high HER3 expression and there was a correlation between HER 3 expression in primary tumors and corresponding lymph node metastases in 236 colorectal cancer patients (25). In addition, elevated HER3 expression was associated with shorter overall survival and disease-free survival in patients with colorectal cancer (25). Furthermore, HER3 downregulation in colorectal cancer cell lines caused G2-M cell-cycle arrest, leading to apoptosis and abrogated cell proliferation, migration, and invasion (22). Altogether, these results suggest that HER3 can be a potential therapeutic target for colorectal cancer.

Several monoclonal antibodies (mAbs) have been established as an innovative immunotherapy against tumors. Programmed cell death 1 (PD-1) and cytotoxic T-lymphocyte-associated protein 4 (CTLA-4) are inhibitory receptors for immune checkpoints, which are expressed on the surface of T cells (26-29). Anti-PD-1 and anti-CTLA-4 $\mathrm{mAbs}$ have been reported as potential anticancer drugs $(30,31)$. Nivolumab and pembrolizumab are anti-PD-1 mAbs, which were approved by the US Food and Drug Administration (32-34). Both mAbs activate the immune system to attack tumors, by blocking the interaction between PD-1 and its ligand, PD-L1, which is expressed in cancer cells. DNA mismatch repair deficient tumors have very high levels of DNA microsatellite instability, and it is known that microsatellite instable tumors have highly upregulated expression of multiple immune checkpoint proteins, including PD-1 compared with microsatellite stable tumors; therefore, nivolumab and pembrolizumab are available for the treatment of DNA mismatch repair deficiency and microsatellite instable subset of colorectal cancer (35-37).

Several antibody drugs have been developed against ligands, such as transforming growth factor (TGF)- $\alpha$ and EGF, or receptors, such as EGFR (38). These mAbs neutralize the interaction between ligands and receptors. Antibody-drug conjugate (ADC) is a complex molecule, which is composed of an antibody, linker, and an anticancer drug, and delivers the anticancer drug to target cells (39). Moreover, some mAbs possess antibody-dependent cellular cytotoxicity (ADCC) or complement-dependent cytotoxicity (CDC). Cetuximab, a mouse/human chimeric $\operatorname{IgG}_{1}$ against EGFR, binds to the ligand-binding site of EGFR, and inhibits the activation and dimerization of EGFR (38). Cetuximab has been used for the treatment of metastatic colorectal cancer, metastatic non-small cell lung cancer, and head and neck squamous cell carcinomas (HNSCC) (38). Trastuzumab, a humanized mAb against HER2, has been used to treat HER2-positive cancers, such as breast cancers and gastric cancers $(40,41)$. Trastuzumab binds to the extracellular domain of HER 2 and downregulates activation of AKT (42). Moreover, trastuzumab exhibited ADCC in a mouse model (43). However, it has been shown that some types of cancers are resistant to cetuximab and trastuzumab $(44,45)$.
Most HNSCCs are resistant to cetuximab, because cetuximab treatment induces HER2/HER3 dimerization and HER3 activation in HNSCC cell lines (44). It has been reported that anti-HER3-ADC exerts antitumor effect on breast cancer cells, which have resistance to trastuzumab (45). For this reason, the development of anti-HER3 mAbs has been required for cancer therapy. Seribantumab and lumretuzumab are anti-HER3 mAbs, which block HER3-neuregulin interaction and inhibit HER3 heterodimerization and phosphorylation $(46,47)$. Lumretuzumab is also known to have ADCC activity (46). Phase II and phase Ib/II trial are now ongoing concerning seribantumab and lumretuzumab, respectively $(47,48)$. An anti-HER3-ADC (U3-1402), composed of an anti-HER3 mAb (patritumab) and a novel topoisomerase I inhibitor (DX-8951 derivative; DXd) has entered phase I and II trials for the treatment of HER3-positive non-small cell lung cancers (NCT04676477), metastatic breast cancers (NCT02980341), and colorectal cancers (NCT04479436) (49-51). Preliminary results demonstrate that U3-1402 treatment appears to be safe and exhibits antitumor activity, suggesting that HER3-targeting therapy may be effective for HER3-overexpressing metastatic breast cancers (50).

It has been reported that one amino acid substitution in EGFR in tumors causes acquisition of resistance to gefitinib after gefitinib treatment $(52,53)$; therefore, HER3 may also acquire resistance to seribantumab and lumretuzumab in the future. To characterize the HER3 and HER3-targeting cancer therapy, the development of further anti-HER3 specific mAbs is required. In this study, we developed a novel anti-HER $3 \mathrm{mAb}$ against colon cancers using a Cell-Based Immunization and Screening (CBIS) method (54). Furthermore, we investigated whether a novel anti-HER $3 \mathrm{mAb}$ shows ADCC/CDC activities or antitumor activities for colon cancers.

\section{Materials and methods}

Construction of plasmids. The Genome Network Project clone IRAK174J18 (HER3) was provided by the RIKEN BioResource Research Center through the National BioResource Project of the MEXT and AMED agencies of Japan. HER3 DNA plus N-terminal PA16 tag, recognized by NZ-1, was subcloned into a pCAG-Ble vector (FUJIFILM Wako Pure Chemical Corp.) and named pCAG/PA16-HER3. HER3 DNA plus C-terminal PA tag, recognized by NZ-1, was subcloned into a pCAG-Neo vector (FUJIFILM Wako Pure Chemical Corp.) and named pCAG/HER3-PA.

Cell lines. A mouse myeloma cell line (P3X63Ag8U.1; P3U1), Chinese hamster ovary (CHO)-K1 cells, a glioblastoma cell line (LN229), colorectal adenocarcinoma cell lines (Caco-2, LS 174T, COLO 201, HCT-8, SW1116, and HT-29), and a colorectal carcinoma cell line (HCT 116) were obtained from the American Type Culture Collection. Colon adenocarcinoma cell lines (HCT-15, COLO 205, and DLD-1) and a breast adenocarcinoma cell line (MCF7) were obtained from the Cell Resource Center for Biomedical Research Institute of Development, Aging and Cancer at Tohoku University. CHO/PA16-HER3 and CHO/HER3-PA were established by transfecting pCAG/PA16-HER3 and pCAG/HER3-PA, respectively, into CHO-K1 cells using the Neon Transfection System 
(Thermo Fisher Scientific, Inc.). A few days after transfection, cells positive for anti-HER3 mAb (clone D22C5; cat. no. 12708; Cell Signaling Technology, Inc.) were sorted using a cell sorter (SH800; Sony Biotechnology Corp.). CHO/mock (Ble) and $\mathrm{CHO} /$ mock (Neo) were established by transfection of the pCAG-Ble vector and pCAG-Neo vector, respectively. Stable transfectants of $\mathrm{CHO} /$ mock (Ble) and CHO/PA16-HER3 were cultured at $37^{\circ} \mathrm{C}$ for 14 days on media containing $0.5 \mathrm{mg} / \mathrm{ml}$ of Zeocin (InvivoGen), and stable transfectants of $\mathrm{CHO} /$ mock (Neo) and $\mathrm{CHO} / \mathrm{HER} 3-\mathrm{PA}$ were cultured at $37^{\circ} \mathrm{C}$ for 14 days on media containing $0.5 \mathrm{mg} / \mathrm{ml}$ of G418 (Nacalai Tesque, Inc.). BINDS-30 [MCF7/HER3-knockout (KO) cells] were produced using CRISPR/Cas9 plasmids targeting human HER3 (http://www.med-tohoku-antibody. com/topics/001_paper_cell.htm). Using TruGuide gRNA tool, gRNA of HER3/ERBB3 (NM_001005915) was selected from GeneArt predesigned gRNAs database (Thermo Fisher Scientific, Inc.). gRNA sequence used was GTCCCGTGA GCACAATCTCA(agg), which targeted exon 3 of HER3 (Assay ID: CRISPR764358). Double strand gRNA sequence was subcloned into GeneArt CRISPR Nuclease Vector with OFP Reporter (Thermo Fisher Scientific, Inc.). P3U1, CHO-K1, CHO/PA16-HER3, CHO/HER3-PA, COLO 201, COLO 205, SW1116, DLD-1, MCF7, and BINDS-30 were cultured in Roswell Park Memorial Institute (RPMI)-1640 media (Nacalai Tesque, Inc.). LN229, Caco-2, HCT 116, HCT-15, HT-29, LS 174T, and HCT-8 were cultured in Dulbecco's modified Eagle's medium (DMEM; Nacalai Tesque, Inc.). RPMI-1640 and DMEM were supplemented with $10 \%$ heat-inactivated fetal bovine serum (FBS; Thermo Fisher Scientific Inc.), $100 \mathrm{U} / \mathrm{ml}$ of penicillin (Nacalai Tesque, Inc.), $100 \mu \mathrm{g} / \mathrm{ml}$ streptomycin (Nacalai Tesque, Inc.), and $0.25 \mu \mathrm{g} / \mathrm{ml}$ amphotericin B (Nacalai Tesque, Inc.), and incubated at $37^{\circ} \mathrm{C}$ in a humidified atmosphere containing $5 \% \mathrm{CO}_{2}$.

Preparation of the purified antibodies. Purified mouse IgG (cat. no. I8765) and mouse $\operatorname{IgG}_{2 a}$ (cat. no. M7769) were purchased from Sigma-Aldrich; Merck KGaA. An anti-HER3 $\mathrm{mAb}$ was purified using Protein G-Sepharose (GE Healthcare BioSciences).

Hybridoma production. Female BALB/c mice (6 weeks old) were purchased from CLEA Japan and kept under specific pathogen-free conditions. All animal experiments were conducted in accordance with the relevant guidelines and regulations in order to minimize animal suffering and distress in the laboratory. The Animal Care and Use Committee of Tohoku University approved all the animal experiments (permit no. 2019NiA-001). Mice were euthanized by cervical dislocation under inhalation anesthesia using $2 \%$ of isoflurane for both induction and maintenance, and the death was verified to be respiratory and cardiac arrest.

CBIS method was used as previously reported (54) to develop mAbs against HER3 (Fig. 1). Two eight-week-old BALB/c female mice were intraperitoneally (i.p.) immunized with $\mathrm{CHO} / \mathrm{PA} 16-\mathrm{HER} 3$ cells $\left(1 \times 10^{8}\right)$ along with Imject Alum adjuvant (Thermo Fisher Scientific, Inc.) (Fig. 1A). The procedure included three additional immunizations, followed by a final booster injection administered i.p. two days before the spleen cell harvesting. Spleen cells were then fused with P3U1 cells using PEG1500 (Roche Diagnostics) (Fig. 1B). The developed hybridomas were seeded into 96-well plates, and hybridomas were grown at $37^{\circ} \mathrm{C}$ for 10 days in RPMI-1640 media with HAT Supplement (50X) (cat. no. 21060017; Thermo Fisher Scientific, Inc.) for selection. Supernatants positive for CHO/HER3-PA and negative for $\mathrm{CHO}-\mathrm{K} 1$ were selected by flow cytometry (Fig. 1C). After limiting dilution, supernatants positive for LN229 were selected by flow cytometry. Finally, anti-HER3 mAb-producing hybridomas were established (Fig. 1D).

Western blot analysis. Cell pellets were resuspended in phosphate-buffered saline (PBS; Nacalai Tesque, Inc.) with 1\% Triton X-100 (cat. no. 168-11805; FUJIFILM Wako Pure Chemical Corp.) and $50 \mu \mathrm{g} / \mathrm{ml}$ aprotinin (product no. 03346-84; Nacalai Tesque, Inc.). Cell debris was removed by centrifugation at $21,880 \mathrm{x}$ g for $10 \mathrm{~min}$ at $4^{\circ} \mathrm{C}$. Protein concentration was determined by BCA method. Cell lysates $(10 \mu \mathrm{g})$ were boiled in sodium dodecyl sulfate (SDS) sample buffer (Nacalai Tesque, Inc.). Proteins were electrophoresed on 5-20\% polyacrylamide gels (FUJIFILM Wako Pure Chemical Corp.) and transferred onto polyvinylidene difluoride (PVDF) membranes (Merck KGaA). After blocking with 4\% skim milk (Nacalai Tesque, Inc.) at room temperature for $30 \mathrm{~min}$, PVDF membranes were incubated with an anti-HER3 mAb (diluted 1:1,000; clone D22C5) and anti- $\beta$-actin mAb (1 $\mu \mathrm{g} / \mathrm{ml}$; clone AC-15; cat. no. A1978; Sigma-Aldrich; Merck KGaA) at room temperature for $30 \mathrm{~min}$, followed by incubation with peroxidase-conjugated anti-rabbit immunoglobulins (diluted 1:1,000; cat. no. P0448; Agilent Technologies Inc.) and peroxidase-conjugated anti-mouse immunoglobulins (diluted 1:1,000; cat. no. P0260; Agilent Technologies Inc.), respectively, at room temperature for $30 \mathrm{~min}$. Blots were developed using ImmunoStar LD (cat. no. 290-69904; FUJIFILM Wako Pure Chemical Corp.) or Pierce ${ }^{\mathrm{TM}}$ ECL Plus Western Blotting Substrate (cat. no. 32132; Thermo Fisher Scientific, Inc.) and imaged with a Sayaca-Imager (DRC Co., Ltd.). Qcapture Pro software (DRC Co., Ltd) was used for the densitometry.

Flow cytometry analyses. Cells $\left(2 \times 10^{5}\right.$ cells $\left./ \mathrm{ml}\right)$ were harvested after brief exposure to $0.25 \%$ trypsin in $1 \mathrm{mM}$ ethylenediaminetetraacetic acid (EDTA; Nacalai Tesque, Inc.). After being washed with $0.1 \%$ bovine serum albumin (BSA, Nacalai Tesque, Inc.) in PBS, cells were treated with $1 \mu \mathrm{g} / \mathrm{ml}$ of anti-HER3 $\mathrm{mAbs}$, for $30 \mathrm{~min}$ at $4^{\circ} \mathrm{C}$, and with Alexa Fluor 488-conjugated anti-mouse IgG $(1: 1,000$; cat. no. 4408; Cell Signaling Technology, Inc.). Fluorescence data were collected using a flow cytometer: the EC800 Cell Analyzer (Sony Biotechnology Corp.).

Determination of the binding affinity. Cells $\left(2 \times 10^{5}\right.$ cells $\left./ \mathrm{ml}\right)$ were suspended in $100 \mu \mathrm{l}$ of serially diluted anti-HER3 $\mathrm{mAb}$ (6 $\mathrm{ng} / \mathrm{ml}-25 \mu \mathrm{g} / \mathrm{ml}$ ), followed by the addition of Alexa Fluor 488-conjugated anti-mouse $\operatorname{IgG}(1: 200)$. Fluorescence data were collected using a flow cytometer: The BD FACSLyric (BD Biosciences). The dissociation constant $\left(K_{\mathrm{D}}\right)$ was calculated by fitting binding isotherms to built-in one-site binding models in GraphPad Prism 8 (GraphPad Software, Inc.).

ADCC activity of an anti-HER3 $m A b$. ADCC inducement by HER3 was assayed as follows. Four female five-week-old $\mathrm{BALB} / \mathrm{c}$ nude mice (mean weight, $15 \pm 3 \mathrm{~g}$ ) were purchased 

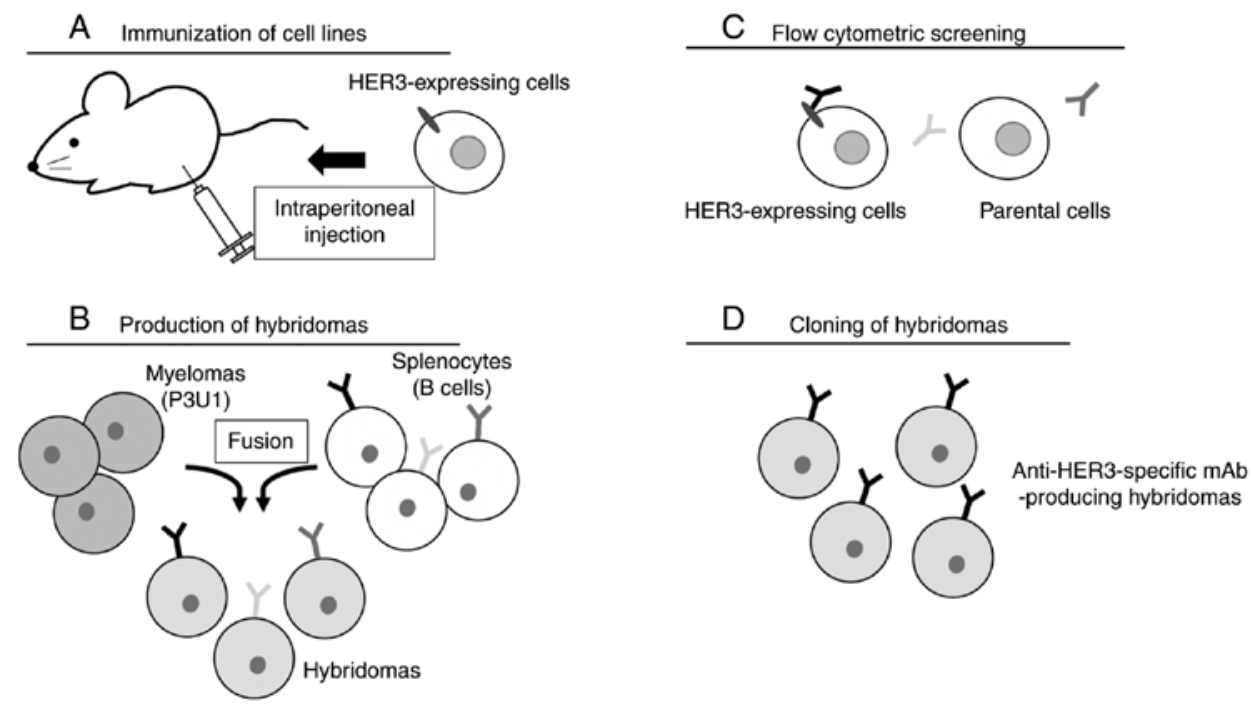

Figure 1. Production of anti-HER3 mAbs. Procedure of the Cell-Based Immunization and Screening (CBIS) method. (A) CHO/PA16-HER3 cells were immunized into BALB/c mice using an intraperitoneal injection. (B) Spleen cells were fused with P3U1 cells. (C) Culture supernatants were screened using flow cytometry. (D) After limiting dilution and several additional screenings, an anti-HER3 mAb was finally established. mAb, monoclonal antibody.

from Charles River Laboratories, Inc. Mice were kept under specific pathogen-free condition on an 11-h light/13-h dark cycle at a temperature of $23 \pm 2^{\circ} \mathrm{C}$ and $55 \pm 5 \%$ humidity with food and water supplied ad libitum during the experimental periods. After euthanasia by cervical dislocation, spleens were removed aseptically, and single-cell suspensions were obtained by forcing spleen tissues through a sterile cell strainer (product no. 352360; Corning, Inc.) with a syringe. Erythrocytes were lysed with a 10-sec exposure to ice-cold distilled water. The splenocytes were washed with DMEM and resuspended in DMEM with $10 \%$ FBS; this preparation was designated as effector cells. The target tumor cells were labeled with $10 \mu \mathrm{g} / \mathrm{ml}$ Calcein-AM (Thermo Fisher Scientific, Inc.) and resuspended in the same medium. The target cells were then transferred to 96-well plates, at $2 \times 10^{4}$ cells/well, and mixed with effector cells at an effector-to-target ratio of 100:1, along with $100 \mu \mathrm{g} / \mathrm{ml}$ of anti-HER3 antibodies or control mouse $\operatorname{IgG}_{2 \mathrm{a}}$. After a 4.5 -h incubation at $37^{\circ} \mathrm{C}$, Calcein release into the supernatant was measured for each well. Fluorescence intensity was assessed using a microplate reader (Power Scan HT; BioTek Instruments, Inc.) with an excitation wavelength of $485 \mathrm{~nm}$ and an emission wavelength of $538 \mathrm{~nm}$. Cytolytic activity was measured as a percentage of lysis and calculated using the equation: Percentage of lysis $(\%)=(\mathrm{E}-\mathrm{S}) /(\mathrm{M}-\mathrm{S}) \times 100$, where $\mathrm{E}$ is the fluorescence measured in combined cultures of target and effector cells, $\mathrm{S}$ is the spontaneous fluorescence of the target cells, and $\mathrm{M}$ is the maximum fluorescence measured after lysis of all cells with buffer containing $0.5 \%$ Triton X-100, $10 \mathrm{mM}$ Tris- $\mathrm{HCl}$ (pH 7.4), and 10 mM EDTA. Animal studies for ADCC were approved by the Institutional Committee for experiments of the Institute of Microbial Chemistry (permit no. 2020-024).

CDC activity of an anti-HER $3 \mathrm{mAb}$. CDC inducement by HER3 was assayed as follows. Target cells were labeled with $10 \mu \mathrm{g} / \mathrm{ml}$ Calcein-AM (Thermo Fisher Scientific, Inc.), resuspended in medium and plated in 96-well plates, at $2 \times 10^{4}$ cells/well, with 15\% rabbit complement (Low-Tox-M rabbit complement; Cedarlane Laboratories), $100 \mu \mathrm{g} / \mathrm{ml}$ of anti-HER3 antibodies, or control $\mathrm{IgG}$ (mouse $\operatorname{IgG}_{2 \mathrm{a}}$ ) added to each well. After $4.5 \mathrm{~h}$ of incubation at $37^{\circ} \mathrm{C}$, Calcein release into the supernatant was measured for each well. Fluorescence intensity was calculated as described in the ADCC section above.

Antitumor activity of an anti-HER3 $m A b$ in xenografts of colon cancers. Sixteen five-week-old female BALB/c nude mice (mean weight, $15 \pm 3 \mathrm{~g}$ ) were purchased from Charles River Laboratories, Inc. All animal experiments were performed in accordance with institutional guidelines and regulations to minimize animal suffering and distress in the laboratory. The Institutional Committee for experiments of the Institute of Microbial Chemistry (permit no. 2020-024) approved the animal studies for antitumor activity here described. Mice were maintained in a pathogen-free environment on an 11-h light/13-h dark cycle at a temperature of $23 \pm 2^{\circ} \mathrm{C}$ and $55 \pm 5 \%$ humidity with food and water supplied ad libitum throughout the experiments. Mice were monitored for health and weight every three or five days. Experiments on mice were conducted in four weeks. Weight loss exceeding $25 \%$ or tumor volume exceeding $3,000 \mathrm{~mm}^{3}$ were identified as humane endpoints for euthanasia. At humane and experimental endpoints, mice were euthanized by cervical dislocation, and death was verified by validating respiratory and cardiac arrest.

After a one-week acclimation period, these mice were used in experiments at six weeks of age (mean weight, $16 \pm 2 \mathrm{~g}$ ). Caco- 2 cells $\left(0.3 \mathrm{ml}\right.$ of $1.33 \times 10^{8}$ cells $/ \mathrm{ml}$ in DMEM) were mixed with $0.5 \mathrm{ml}$ BD Matrigel Matrix Growth Factor Reduced (BD Biosciences), and $100 \mu \mathrm{l}$ of this suspension $\left(5 \times 10^{6}\right.$ cells) was injected subcutaneously into the left flank of each animal. On the eighth day post-inoculation, 16 mice were divided into two groups ( $\mathrm{n}=8$ in each group) with equal mean tumor volume: An anti-HER $3 \mathrm{mAb}$ group or a control mouse $\operatorname{IgG}$ group. Then, $100 \mu \mathrm{g}$ of an anti-HER $3 \mathrm{mAb}$ or control mouse IgG in $100 \mu 1$ PBS was injected i.p. Additional antibody inoculations were performed on days 15 and 23. Twenty-six days after cell implantation, all mice were euthanized by cervical dislocation, and tumor diameters and volumes were measured and recorded. 


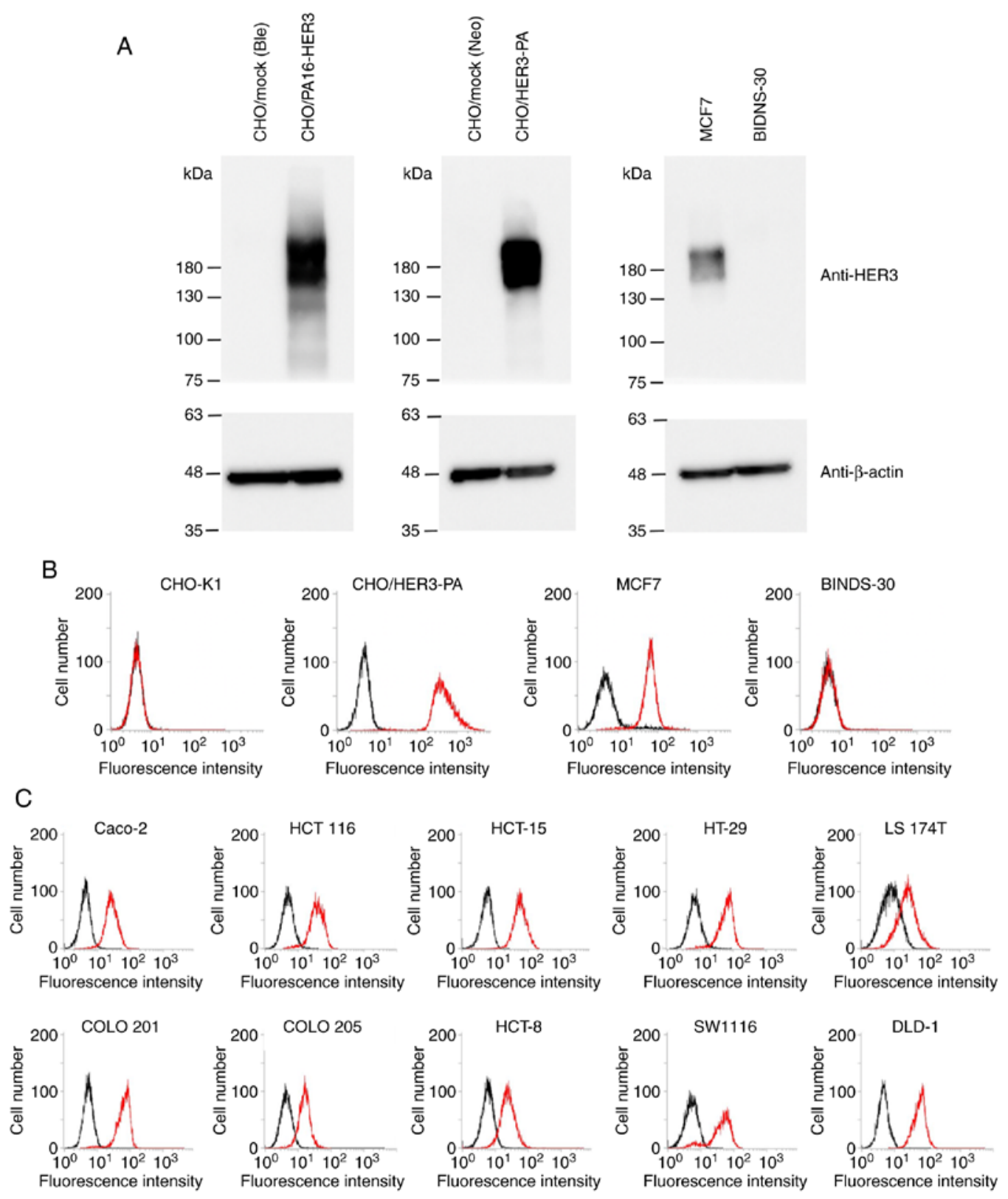

Figure 2. Characterization of $\mathrm{H}_{3} \mathrm{Mab}-17$. (A) Confirmation of HER3 expression by western blot analysis. Cell lysates were electrophoresed and transferred onto PVDF membranes. After blocking, PVDF membranes were incubated with an anti-HER3 mAb (clone D22C5) or anti- $\beta$-actin (clone AC-15), followed by incubation with peroxidase-conjugated anti-rabbit immunoglobulins or peroxidase-conjugated anti-mouse immunoglobulins. Blots were developed using ImmunoStar LD or ECL Plus Western Blotting Substrate and imaged with a Sayaca-Imager. (B) Flow cytometry analysis. CHO-K1, CHO/HER3-PA, MCF7, and BINDS-30 cells were treated with $1 \mu \mathrm{g} / \mathrm{ml}$ of $\mathrm{H}_{3} \mathrm{Mab}-17$, followed by treatment with Alexa Fluor 488-conjugated anti-mouse IgG. Black line, negative control. (C) Flow cytometry analysis. Colon cancer cell lines, such as Caco-2, HCT 116, HCT-15, HT-29, LS 174T, COLO 201, COLO 205, HCT-8, SW1116, and DLD-1 cells were treated with $1 \mu \mathrm{g} / \mathrm{ml}$ of $\mathrm{H}_{3} \mathrm{Mab}-17$, followed by treatment with Alexa Fluor 488-conjugated anti-mouse IgG. Black line, negative control. mAb, monoclonal antibody.

Statistical analyses. All data are expressed as mean \pm standard error of the mean (SEM). Statistical analysis was conducted with ANOVA and Tukey's multiple comparisons tests for ADCC and CDC, ANOVA and Sidak's multiple comparisons tests for tumor volume and mouse weight, and Welch's t-test for tumor weight. All calculations were performed with GraphPad Prism 8 (GraphPad Software, Inc.). A P-value of $<0.05$ was considered to indicate a statistically significant difference.

\section{Results}

Development of anti-HER3 $m A b s$. We employed the CBIS method to develop anti-HER3 mAbs using CHO/PA16-HER3 cells both for the immunization and flow cytometry screening (Fig. 1). The developed hybridomas were seeded into 96-well plates and cultivated for 10 days. Supernatants positive for CHO/HER3-PA and negative for CHO-K1 were selected by flow cytometry. After limiting dilution and several additional screenings, an anti-HER $3 \mathrm{mAb}, \mathrm{H}_{3} \mathrm{Mab}-17$ (mouse $\mathrm{IgG}_{2 \mathrm{a}}$, kappa), was finally established.

Confirmation of HER3 expression by western blot analysis. We established $\mathrm{CHO} /$ mock (Ble), CHO/PA16-HER3, $\mathrm{CHO} /$ mock (Neo), and $\mathrm{CHO} / \mathrm{HER} 3-\mathrm{PA}$, and investigated whether HER 3 was overexpressed in those cell lines. As shown in Fig. 2A, overexpression of HER3 in CHO/PA16-HER3 and 

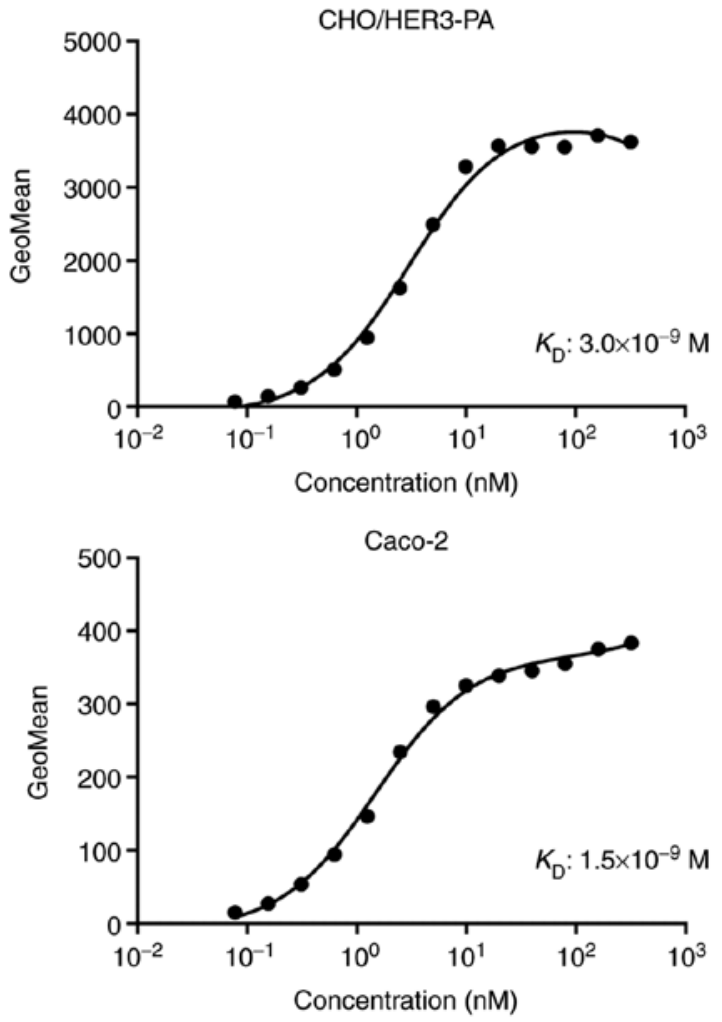

Figure 3. Determination of the binding affinity of $\mathrm{H}_{3} \mathrm{Mab}-17$. CHO/HER3-PA and Caco-2 were suspended in $100 \mu \mathrm{l}$ of serially diluted $\mathrm{H}_{3}$ Mab-17 $(0.006-25 \mu \mathrm{g} / \mathrm{ml})$ prior to Alexa Fluor 488-conjugated anti-mouse IgG addition. Fluorescence data were collected using a BD FACSLyric. $K_{\mathrm{D}}$, dissociation constant.

CHO/HER3-PA was confirmed by western blot analysis using an anti-HER3 mAb (clone D22C5). Endogenous HER3 expression in MCF7 cells was also detected by an anti-HER3 mAb. In contrast, knockout of endogenous HER 3 in BINDS-30 (MCF7/HER3-KO) was confirmed by western blot analysis using an anti-HER3 mAb.

Flow cytometry analyses of $\mathrm{H}_{3} \mathrm{Mab}-17$. We performed flow cytometry using $\mathrm{H}_{3} \mathrm{Mab}-17$ against $\mathrm{CHO}-\mathrm{K} 1$, CHO/HER3-PA, MCF7, and BINDS-30 (MCF7/HER3-KO). $\mathrm{H}_{3} \mathrm{Mab}-17$ recognized the $\mathrm{CHO} / \mathrm{HER} 3-\mathrm{PA}$ cells, but not the parental CHO-K1 cells (Fig. 2B). $\mathrm{H}_{3} \mathrm{Mab}-17$ also recognized the endogenous HER3 in MCF7 breast cancer cells (Fig. 2B). The reaction of $\mathrm{H}_{3} \mathrm{Mab}-17$ to BINDS-30 was lost after the knockout of HER3 in MCF7 cells (Fig. 2B), indicating the specificity of $\mathrm{H}_{3} \mathrm{Mab}-17$ for HER3.

Next, we investigated whether $\mathrm{H}_{3} \mathrm{Mab}-17$ reacts with colon cancer cell lines. As shown in Fig. 2C, $\mathrm{H}_{3} \mathrm{Mab}-17$ reacted with 10 colon cancer cell lines, Caco-2, HCT 116, HCT-15, HT-29, LS 174T, COLO 201, COLO 205, HCT-8, SW1116, and DLD-1. Among them, Caco-2 was known to be useful for the mouse xenograft model (55). Therefore, we used Caco-2 cells for the $\mathrm{ADCC} / \mathrm{CDC}$ assay or in vivo xenograft models.

Determination of the binding affinity of $\mathrm{H}_{3} \mathrm{Mab}-17$. A kinetic analysis of the interactions of $\mathrm{H}_{3} \mathrm{Mab}-17$ with $\mathrm{CHO} / \mathrm{HER} 3-\mathrm{PA}$ and Caco-2 cells was then conducted using flow cytometry. The $K_{\mathrm{D}}$ for $\mathrm{H}_{3} \mathrm{Mab}-17$ in CHO/HER3-PA and Caco-2 cells
A
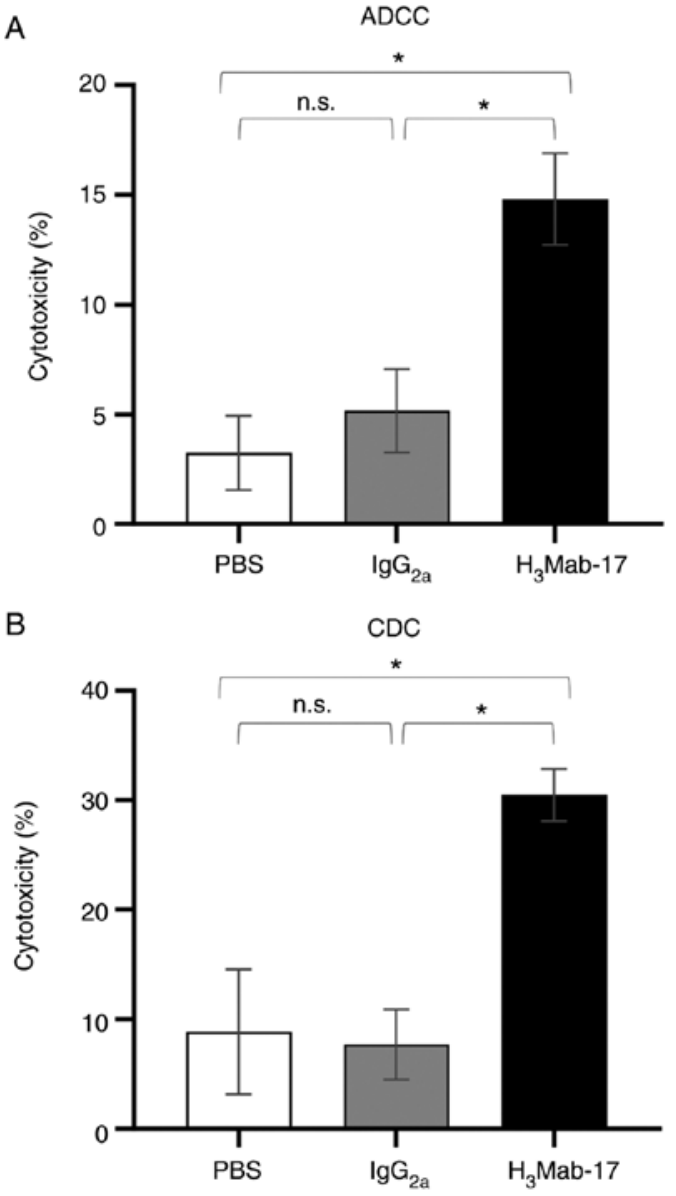

Figure 4. Evaluation of ADCC and CDC activities by $\mathrm{H}_{3} \mathrm{Mab}-17$. (A) ADCC activities by $\mathrm{H}_{3} \mathrm{Mab}-17$, control mouse $\mathrm{IgG}_{2 \mathrm{a}}$, and control PBS in Caco-2 cells. (B) CDC activities by $\mathrm{H}_{3} \mathrm{Mab}-17$, control mouse $\mathrm{IgG}_{2 \mathrm{a}}$, and control PBS in Caco-2 cells. Values are mean \pm SEM. Asterisk indicates statistical significance ( $\mathrm{P}<0.05$; n.s., not significant, ANOVA and Tukey-Kramer's test). ADCC, antibody-dependent cellular cytotoxicity; CDC, complement-dependent cytotoxicity.

were $3.0 \times 10^{-9}$ and $1.5 \times 10^{-9} \mathrm{M}$, respectively (Fig. 3), indicating high binding affinity of $\mathrm{H}_{3} \mathrm{Mab}-17$ against HER3-expressing cells.

ADCC and CDC activities of $\mathrm{H}_{3} \mathrm{Mab}-17$ in colon cancer cell lines. We then examined whether $\mathrm{H}_{3} \mathrm{Mab}-17$ (mouse $\mathrm{IgG}_{2 \mathrm{a}}$ ) induced ADCC and CDC activity in HER3-expressing Caco-2 colon cancer cell lines. $\mathrm{H}_{3} \mathrm{Mab}-17$ exhibited higher ADCC (14.8\% cytotoxicity) in Caco-2 cells than that of control mouse $\mathrm{IgG}_{2 \mathrm{a}}(5.2 \%$ cytotoxicity; $\mathrm{P}<0.05)$ or control PBS $(3.2 \%$ cytotoxicity; $\mathrm{P}<0.05)$ treatment (Fig. $4 \mathrm{~A}) . \mathrm{H}_{3} \mathrm{Mab}-17$ was also associated with a more robust CDC activity $(30.4 \%$ cytotoxicity) in Caco- 2 cells than the control mouse $\operatorname{IgG}_{2 \mathrm{a}}$ (7.7\% cytotoxicity; $\mathrm{P}<0.05)$ or the control with PBS treatment $(8.8 \%$ cytotoxicity; $\mathrm{P}<0.05)$ (Fig. 4B). These favorable ADCC/CDC activities indicated that $\mathrm{H}_{3} \mathrm{Mab}-17$ may induce strong antitumor activity against colon cancer cells in vivo as well as in vitro.

Antitumor effect of $\mathrm{H}_{3} \mathrm{Mab}-17$ in mouse xenografts of colon cancer cells. Tumor formation of $16 \mathrm{Caco}-2$-bearing mice was observed on day eight. Then, these 16 Caco-2-bearing mice 
A

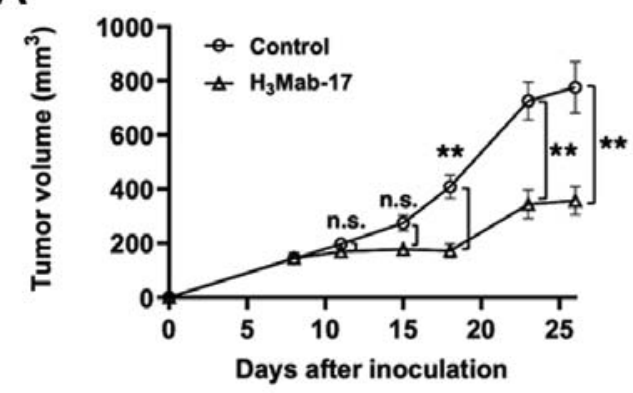

B

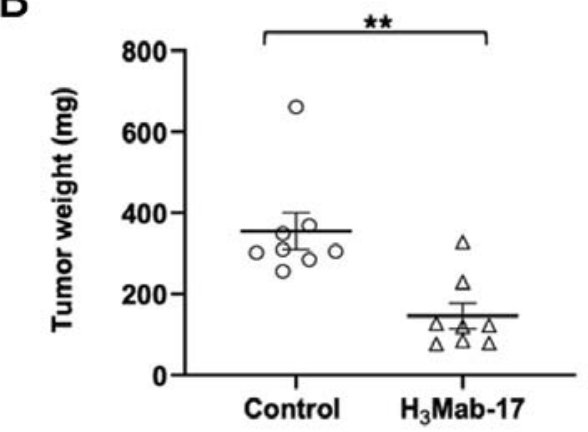

C

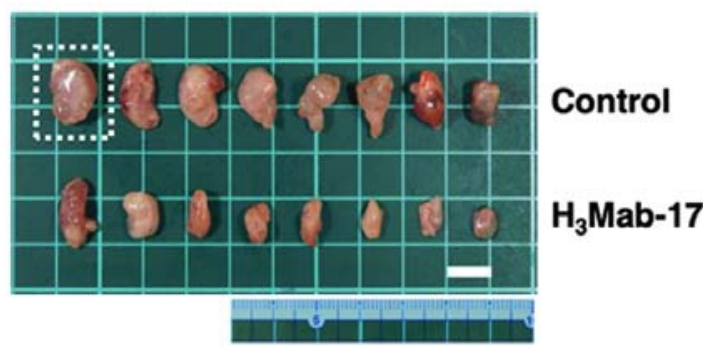

Figure 5. Evaluation of antitumor activity of $\mathrm{H}_{3} \mathrm{Mab}-17$ in Caco-2 xenografts

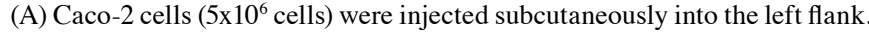
After day 8, $100 \mu \mathrm{g}$ of $\mathrm{H}_{3} \mathrm{Mab}-17$ and control mouse IgG in $100 \mu \mathrm{l}$ PBS were injected i.p. into the treated and control mice, respectively. Additional antibodies were then injected on days 15 and 23. Tumor volume was measured on days 8,11, 15, 18, 23 and 26. Values are mean \pm SEM. Asterisk indicates statistical significance $\left({ }^{* *} \mathrm{P}<0.01\right.$; n.s., not significant, ANOVA and Sidak's multiple comparisons test). $\mathrm{O}$, control; $\triangle, \mathrm{H}_{3} \mathrm{Mab}-17$. (B) Tumors of Caco-2 xenografts were resected from $\mathrm{H}_{3} \mathrm{Mab}-17$ and control mouse IgG groups. Tumor weight on day 26 was measured from excised xenografts. Values are mean \pm SEM. Asterisk indicates statistical significance $\left({ }^{* *} \mathrm{P}<0.01\right.$, Welch's t-test). $\mathrm{O}$, control; $\triangle, \mathrm{H}_{3}$ Mab-17. (C) Resected tumors of Caco-2 xenografts from $\mathrm{H}_{3} \mathrm{Mab}-17$ and control mouse IgG groups on day 26. The tumor in the square dotted region was the largest tumor in this experiment. The vertical and horizontal lengths for Caco-2 cells were 1.6 and $1.3 \mathrm{~cm}$, respectively (estimated tumor volume, 1,352 $\mathrm{mm}^{3}$, tumor weight, $661 \mathrm{mg}$ ). Scale bar, $1 \mathrm{~cm}$

were divided into an $\mathrm{H}_{3} \mathrm{Mab}$-17-treated group and a control group. On days 8,15 and 23 after Caco- 2 cell injections into the mice, $\mathrm{H}_{3} \mathrm{Mab}-17(100 \mu \mathrm{g})$ or control mouse IgG $(100 \mu \mathrm{g})$ were injected i.p. in the Caco- 2 xenograft model mice. The tumor volume was measured on days $8,11,15,18,23$ and 26 after the Caco-2 cell injection. $\mathrm{H}_{3} \mathrm{Mab}-17$-treated mice exhibited significantly less tumor growth on day $18(\mathrm{P}<0.01)$, day 23 $(\mathrm{P}<0.01)$, and day $26(\mathrm{P}<0.01)$, compared with the IgG-treated control mice (Fig. 5A). The reduction in the volume of the tumors by $\mathrm{H}_{3} \mathrm{Mab}-17$ treatment was of $54 \%$ on day 26 . Tumors from the $\mathrm{H}_{3} \mathrm{Mab}$-17-treated mice weighed significantly less than tumors from the IgG-treated control mice $(59 \%$ reduction, $\mathrm{P}<0.01$; Fig. 5B). Resected tumors on day 26 are presented

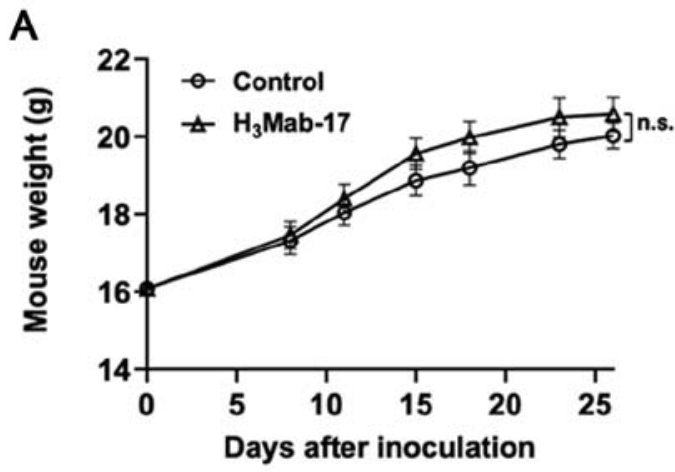

B
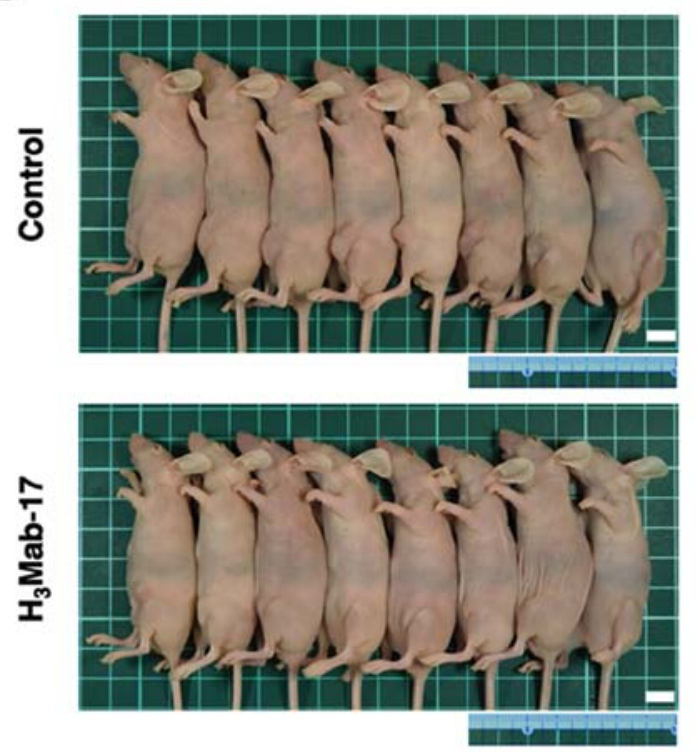

Figure 6. Body weights of mice implanted with Caco-2 xenografts. Caco-2 cells $\left(5 \times 10^{6}\right.$ cells) were injected subcutaneously into the left flank. After day $8,100 \mu \mathrm{g}$ of $\mathrm{H}_{3} \mathrm{Mab}-17$ and control mouse IgG in $100 \mu \mathrm{l}$ PBS were injected i.p. into treated and control mice, respectively. Additional antibodies were then injected on days 15 and 23. (A) Body weights of the mice with the Caco-2 xenografts of $\mathrm{H}_{3} \mathrm{Mab}-17$ group and control group were recorded on days $8,11,15,18,23$ and 26 . Values are mean \pm SEM. n.s. indicates no statistical significance (ANOVA and Sidak's multiple comparisons test). (B) Body appearance of mice with the Caco-2 xenografts of $\mathrm{H}_{3} \mathrm{Mab}-17$ and control mouse $\mathrm{IgG}$ groups on day 26 . Scale bar, $1 \mathrm{~cm}$.

in Fig. 5C. The total body weights did not significantly differ between the treatment and control groups (Fig. 6A and B). These results indicated that $\mathrm{H}_{3} \mathrm{Mab}-17$ reduced the growth of Caco-2 xenografts, without eliminating them completely.

\section{Discussion}

Many commercially available anti-HER3 mAbs have been developed using recombinant HER3 protein, peptide or cDNA as an immunogen. Seribantumab was developed by phage display $(56,57)$ and lumretuzumab was developed using recombinant HER3 extracellular domain as an immunogen (46). In this study, we succeeded in the development of an anti-HER3 mAb using the CBIS method, which used HER3-expressed cells for both immunization and screening. The CBIS method can help us effectively develop mAbs that are useful in flow cytometry. We recently succeeded in developing numerous useful mAbs that target membrane 
proteins, including podoplanin (58-61), CD20 (62), CD44 (63), CD133 (54), and TROP2 $(64,65)$. Importantly, these mAbs are very useful for various experiments, including not only flow cytometry, but also western blot analysis and immunohistochemistry. Furthermore, those mAbs possess ADCC/CDC activities and antitumor activities (61). Using the CBIS method, proteins for immunogen expressed on cells maintain its native conformation and glycosylation pattern. Previously, we successfully established a cancer-specific mAb (CasMab) against podoplanin, which recognizes the cancer cell-specific glycosylation of podoplanin (66). Therefore, we may develop CasMab against HER3 using the CBIS method in the future. The CBIS method is advantageous for the development for specific and sensitive mAbs for antibody therapy.

New highly accurate therapeutic options are possible to treat most solid tumors. In the case of colorectal cancer, HER3 overexpression is found in $\sim 17-75 \%$, although the definition of its cutoff signals for HER 3 expression are different in each immunohistochemical study (67). It has been reported that the incidence of HER3 overexpression in metastatic colorectal cancer is much higher than that of HER2 (68). In this study, we developed an anti-HER3 $\mathrm{mAb}, \mathrm{H}_{3} \mathrm{Mab}-17$, which specifically reacted with endogenous HER 3 in colorectal carcinoma cell lines in flow cytometry. The $K_{\mathrm{D}}$ for $\mathrm{H}_{3} \mathrm{Mab}-17$ in CHO/HER3-PA and Caco-2 cells were determined to be $3.0 \times 10^{-9}$ and $1.5 \times 10^{-9} \mathrm{M}$, respectively, suggesting high binding affinity of $\mathrm{H}_{3} \mathrm{Mab}-17$ for HER3. In vitro experiments revealed strong ADCC and CDC inducement against Caco-2 cells by $\mathrm{H}_{3}$ Mab-17. In vivo experiments on Caco-2 xenografts revealed that the treatment with $\mathrm{H}_{3} \mathrm{Mab}-17$ significantly reduced the tumor growth, compared with the control mouse IgG. Based on these findings, $\mathrm{H}_{3} \mathrm{Mab}-17$ may be useful in therapeutic approach for patients with colorectal cancer.

Although $\mathrm{H}_{3}$ Mab-17 recognizes both overexpressed and endogenous HER 3 by flow cytometric analyses, it is not applicable to western blot and immunohistochemical analyses (data not shown). $\mathrm{H}_{3}$ Mab-17 did not recognize denatured HER3, such as SDS-treated and formalin-fixed HER3 probably because it might recognize the three-dimensional structure of HER3. Since the antitumor activity mechanism of $\mathrm{H}_{3} \mathrm{Mab}-17$ has not been clarified, we need to identify the epitope of $\mathrm{H}_{3} \mathrm{Mab}-17$ and investigate the inhibitory activity of HER3-neureglin interaction of $\mathrm{H}_{3} \mathrm{Mab}-17$. Furthermore, HER3-ADC and HER3-chimeric antigen receptor (CAR)-T should be developed in future research.

\section{Acknowledgements}

We would like to thank Ms. Miyuki Yanaka, Ms. Saori Handa, and Mr. Yu Komatsu (Department of Antibody Drug Development, Tohoku University Graduate School of Medicine) for technical assistance in the in vitro experiments, and Ms. Akiko Harakawa [Institute of Microbial Chemistry (BIKAKEN), Numazu, Microbial Chemistry Research Foundation] for technical assistance in the animal experiments.

\section{Funding}

This research was supported in part by the Japan Agency for Medical Research and Development (AMED) under grant nos. JP21am0401013 (to YK) and JP21am0101078 (to YK), and by the Japan Society for the Promotion of Science (JSPS) Grants-in-Aid for Scientific Research (KAKENHI) grant nos. 21K15523 (to TA), 21K07168 (to MKK), 19K07705 (to YK) and 20K16322 (to MS).

\section{Availability of data and materials}

The datasets used and/or analyzed during the study are available from the corresponding author on reasonable request.

\section{Authors' contributions}

TA, TO, TN, RN, HHo, TT, and MS performed the experiments. JT and MKK analyzed the experimental data. HHa, MK, and YK designed the present study. TA, TO, and YK wrote the manuscript. All the authors read and approved the final manuscript for publishing.

\section{Ethics approval and consent to participate}

The Animal Care and Use Committee of Tohoku University approved all the animal experiments (permit no. 2019NiA-001). Animal studies for ADCC and the antitumor activity were approved by the Institutional Committee for experiments of the Institute of Microbial Chemistry (permit no. 2020-024).

\section{Patient consent for publication}

Not applicable.

\section{Competing interests}

The authors declare that they have no competing interests.

\section{References}

1. Gschwind A, Fischer OM and Ullrich A: The discovery of receptor tyrosine kinases: Targets for cancer therapy. Nat Rev Cancer 4: 361-370, 2004.

2. Yarden $Y$ and Sliwkowski MX: Untangling the ErbB signalling network. Nat Rev Mol Cell Biol 2: 127-137, 2001.

3. Schlessinger J: Ligand-induced, receptor-mediated dimerization and activation of EGF receptor. Cell 110: 669-672, 2002.

4. Scaltriti $\mathrm{M}$ and Baselga J: The epidermal growth factor receptor pathway: A model for targeted therapy. Clin Cancer Res 12: 5268-5272, 2006.

5. Schreiber AB, Libermann TA, Lax I, Yarden Y and Schlessinger J: Biological role of epidermal growth factor-receptor clustering. Investigation with monoclonal anti-receptor antibodies. J Biol Chem 258: 846-853, 1983.

6. Linggi B and Carpenter G: ErbB receptors: New insights on mechanisms and biology. Trends Cell Biol 16: 649-656, 2006.

7. Harris RC, Chung E and Coffey RJ: EGF receptor ligands. Exp Cell Res 284: 2-13, 2003.

8. Citri A, Skaria KB and Yarden Y: The deaf and the dumb: The biology of ErbB-2 and ErbB-3. Exp Cell Res 284: 54-65, 2003.

9. Guy PM,Platko JV, Cantley LC, Cerione RA and Carraway KL III: Insect cell-expressed p180erbB3 possesses an impaired tyrosine kinase activity. Proc Natl Acad Sci USA 91: 8132-8136, 1994.

10. Holbro T, Beerli RR, Maurer F, Koziczak M, Barbas CF 3rd and Hynes NE: The ErbB2/ErbB3 heterodimer functions as an oncogenic unit: ErbB2 requires ErbB3 to drive breast tumor cell proliferation. Proc Natl Acad Sci USA 100: 8933-8938, 2003.

11. Akhtar S, Chandrasekhar B, Attur S, Dhaunsi GS, Yousif MH and Benter IF: Transactivation of ErbB family of receptor tyrosine kinases is inhibited by angiotensin-(1-7) via its mas receptor. PLoS One 10: e0141657, 2015. 
12. Ceresa BP and Vanlandingham PA: Molecular mechanisms that regulate epidermal growth factor receptor inactivation. Clin Med Oncol 2: 47-61, 2008.

13. Henriksen L, Grandal MV, Knudsen SL, van Deurs B and Grøvdal LM: Internalization mechanisms of the epiderma growth factor receptor after activation with different ligands. PLoS One 8: e58148, 2013.

14. Bublil EM and Yarden Y: The EGF receptor family: Spearheading a merger of signaling and therapeutics. Curr Opin Cell Biol 19: 124-134, 2007

15. Yarden Y and Pines G: The ERBB network: At last, cancer therapy meets systems biology. Nat Rev Cancer 12: 553-563, 2012.

16. Hendler FJ and Ozanne BW: Human squamous cell lung cancers express increased epidermal growth factor receptors. J Clin Invest 74: 647-651, 1984.

17. Kraus MH, Popescu NC, Amsbaugh SC and King CR: Overexpression of the EGF receptor-related proto-oncogene erbB-2 in human mammary tumor cell lines by different molecular mechanisms. EMBO J 6: 605-610, 1987.

18. Appert-Collin A, Hubert P, Crémel G and Bennasroune A: Role of ErbB receptors in cancer cell migration and invasion. Front Pharmacol 6: 283, 2015 .

19. Lai WW, Chen FF, Wu MH, Chow NH, Su WC, Ma MC, Su PF, Chen H, Lin MY and Tseng YL: Immunohistochemical analysis of epidermal growth factor receptor family members in stage non-small cell lung cancer. Ann Thorac Surg 72: 1868-1876, 2001.

20. Koutsopoulos AV, Mavroudis D, Dambaki KI, Souglakos J, Tzortzaki EG, Drositis J, Delides GS, Georgoulias V and Stathopoulos EN: Simultaneous expression of c-erbB-1, c-erbB-2, c-erbB-3 and c-erbB-4 receptors in non-small-cell lung carcinomas: Correlation with clinical outcome. Lung Cancer 57: 193-200, 2007

21. Davies S, Holmes A, Lomo L, Steinkamp MP, Kang H, Muller CY and Wilson BS: High incidence of ErbB3, ErbB4, and MET expression in ovarian cancer. Int J Gynecol Pathol 33 402-410, 2014.

22. Beji A, Horst D, Engel J, Kirchner T and Ullrich A: Toward the prognostic significance and therapeutic potential of HER3 receptor tyrosine kinase in human colon cancer. Clin Cancer Res 18: 956-968, 2012.

23. Ocana A, Vera-Badillo F, Seruga B, Templeton A, Pandiella A and Amir E: HER3 overexpression and survival in solid tumors: A meta-analysis. J Natl Cancer Inst 105: 266-273, 2013.

24. Bray F, Ferlay J, Soerjomataram I, Siegel RL, Torre LA and Jemal A: Global cancer statistics 2018: GLOBOCAN estimates of incidence and mortality worldwide for 36 cancers in 185 countries. CA Cancer J Clin 68: 394-424, 2018

25. Ledel F, Hallstrom M, Ragnhammar P, Ohrling K and Edler D: HER3 expression in patients with primary colorectal cancer and corresponding lymph node metastases related to clinical outcome. Eur J Cancer 50: 656-662, 2014.

26. Nishimura $H$, Nose $M$, Hiai $H$, Minato $N$ and Honjo $T$ : Development of lupus-like autoimmune diseases by disruption of the PD-1 gene encoding an ITIM motif-carrying immunoreceptor. Immunity 11: 141-151, 1999.

27. Nishimura H, Minato N, Nakano T and Honjo T: Immunological studies on PD-1 deficient mice: Implication of PD-1 as a negative regulator for B cell responses. Int Immunol 10: 1563-1572, 1998.

28. Engelhardt JJ, Sullivan TJ and Allison JP: CTLA-4 overexpression inhibits T cell responses through a CD28-B7-dependent mechanism. J Immunol 177: 1052-1061, 2006.

29. Sharma P and Allison JP: The future of immune checkpoint therapy. Science 348: 56-61, 2015.

30. Borghaei H, Paz-Ares L, Horn L, Spigel DR, Steins M, Ready NE, Chow LQ, Vokes EE, Felip E, Holgado E, et al: Nivolumab versus docetaxel in advanced nonsquamous Non-Small-Cell lung cancer. N Engl J Med 373: 1627-1639, 2015.

31. Hodi FS, O'Day SJ, McDermott DF, Weber RW, Sosman JA, Haanen JB, Gonzalez R, Robert C, Schadendorf D, Hassel JC, et al: Improved survival with ipilimumab in patients with metastatic melanoma. N Engl J Med 363: 711-723, 2010.

32. Golshani $G$ and Zhang Y: Advances in immunotherapy for colorectal cancer: A review. Therap Adv Gastroenterol 13: 1756284820917527,2020

33. Le DT, Durham JN, Smith KN, Wang H, Bartlett BR, Aulakh LK, Lu S, Kemberling H, Wilt C, Luber BS, et al: Mismatch repair deficiency predicts response of solid tumors to PD-1 blockade. Science 357: 409-413, 2017.
34. Overman MJ, McDermott R, Leach JL, Lonardi S, Lenz HJ, Morse MA, Desai J, Hill A, Axelson M, Moss RA, et al: Nivolumab in patients with metastatic DNA mismatch repair-deficient or microsatellite instability-high colorectal cancer (CheckMate 142): An open-label, multicentre, phase 2 study. Lancet Oncol 18: 1182-1191, 2017.

35. Xiao Y and Freeman GJ: The microsatellite instable subset of colorectal cancer is a particularly good candidate for checkpoint blockade immunotherapy. Cancer Discov 5: 16-18, 2015.

36. Llosa NJ, Cruise M, Tam A, Wicks EC, Hechenbleikner EM, Taube JM, Blosser RL, Fan H, Wang H, Luber BS, et al: The vigorous immune microenvironment of microsatellite instable colon cancer is balanced by multiple counter-inhibitory checkpoints. Cancer Discov 5: 43-51, 2015.

37. Le DT, Uram JN, Wang H, Bartlett BR, Kemberling H, Eyring AD, Skora AD, Luber BS, Azad NS, Laheru D, et al: PD-1 blockade in tumors with mismatch-repair deficiency. N Engl J Med 372: 2509-2520, 2015.

38. Li S, Schmitz KR, Jeffrey PD, Wiltzius JJ, Kussie P and Ferguson KM: Structural basis for inhibition of the epidermal growth factor receptor by cetuximab. Cancer Cell 7: 301-311, 2005.

39. Flygare JA, Pillow TH and Aristoff P: Antibody-drug conjugates for the treatment of cancer. Chem Biol Drug Des 81: 113-121, 2013.

40. Slamon DJ, Leyland-Jones B, Shak S, Fuchs H, Paton V, Bajamonde A, Fleming T, Eiermann W, Wolter J, Pegram M, et al: Use of chemotherapy plus a monoclonal antibody against HER2 for metastatic breast cancer that overexpresses HER2. N Engl J Med 344: 783-792, 2001.

41. Bang YJ, Van Cutsem E, Feyereislova A, Chung HC, Shen L, Sawaki A, Lordick F, Ohtsu A, Omuro Y, Satoh T, et al: Trastuzumab in combination with chemotherapy versus chemotherapy alone for treatment of HER2-positive advanced gastric or gastro-oesophageal junction cancer (ToGA): A phase 3, open-label, randomised controlled trial. Lancet 376: 687-697, 2010.

42. Kute T, Lack CM, Willingham M, Bishwokama B, Williams H, Barrett K, Mitchell T and Vaughn JP: Development of Herceptin resistance in breast cancer cells. Cytometry A 57: 86-93, 2004

43. Clynes RA, Towers TL, Presta LG and Ravetch JV: Inhibitory Fc receptors modulate in vivo cytotoxicity against tumor targets. Nat Med 6: 443-446, 2000

44. Wang D, Qian G, Zhang H, Magliocca KR, Nannapaneni S, Amin AR, Rossi M, Patel M, El-Deiry M, Wadsworth JT, et al: HER 3 targeting sensitizes HNSCC to Cetuximab by reducing HER3 activity and HER2/HER3 dimerization: Evidence from cell line and Patient-Derived xenograft models. Clin Cancer Res 23: 677-686, 2017.

45. Gandullo-Sánchez L, Capone E, Ocaña A, Iacobelli S, Sala G and Pandiella A: HER3 targeting with an antibody-drug conjugate bypasses resistance to anti-HER2 therapies. EMBO Mol Med 12: e11498, 2020.

46. Mirschberger C, Schiller CB, Schräml M, Dimoudis N, Friess T, Gerdes CA, Reiff U, Lifke V, Hoelzlwimmer G, Kolm I, et al: RG7116, a therapeutic antibody that binds the inactive HER3 receptor and is optimized for immune effector activation. Cancer Res 73: 5183-5194, 2013.

47. Sequist LV, Gray JE, Harb WA, Lopez-Chavez A, Doebele RC, Modiano MR, Jackman DM, Baggstrom MQ, Atmaca A, Felip E, et al: Randomized Phase II trial of seribantumab in combination with erlotinib in patients with EGFR wild-type non-small cell lung cancer. Oncologist 24: 1095-1102, 2019.

48. Cejalvo JM, Jacob W, Fleitas Kanonnikoff T, Felip E, Navarro Mendivil A, Martinez Garcia M, Taus Garcia A, Leighl N, Lassen U, Mau-Soerensen M, et al: A phase Ib/II study of HER3-targeting lumretuzumab in combination with carboplatin and paclitaxel as first-line treatment in patients with advanced or metastatic squamous non-small cell lung cancer. ESMO Open 4: e000532, 2019.

49. Koganemaru S, Kuboki Y, Koga Y, Kojima T, Yamauchi M, Maeda N, Kagari T, Hirotani K, Yasunaga M, Matsumura Y and Doi T: U3-1402, a Novel HER3-Targeting Antibody-Drug conjugate, for the treatment of colorectal cancer. Mol Cancer Ther 18: 2043-2050, 2019.

50. Masuda N, Yonemori K, Takahashi S, Kogawa T, Nakayama T, Iwase H, Takahashi M, Toyama T, Saeki T, Saji S, et al: Abstract PD1-03: Single agent activity of U3-1402, a HER3-targeting antibody-drug conjugate, in HER3-overexpressing metastatic breast cancer: Updated results of a phase 1/2 trial. Cancer Res 79, 2019. 
51. Hashimoto Y, Koyama K, Kamai Y, Hirotani K, Ogitani Y, Zembutsu A, Abe M, Kaneda Y, Maeda N, Shiose Y, et al: A Novel HER3-Targeting Antibody-Drug Conjugate, U3-1402, exhibits potent therapeutic efficacy through the delivery of cytotoxic payload by efficient internalization. Clin Cancer Res 25 7151-7161, 2019.

52. Pao W, Miller VA, Politi KA, Riely GJ, Somwar R, Zakowski MF, Kris MG and Varmus H: Acquired resistance of lung adenocarcinomas to gefitinib or erlotinib is associated with a second mutation in the EGFR kinase domain. PLoS Med 2: e73, 2005.

53. Kobayashi S, Boggon TJ, Dayaram T, Jänne PA, Kocher O, Meyerson M, Johnson BE, Eck MJ, Tenen DG and Halmos B: EGFR mutation and resistance of non-small-cell lung cancer to gefitinib. N Engl J Med 352: 786-792, 2005.

54. Itai S, Fujii Y, Nakamura T, Chang YW, Yanaka M, Saidoh N, Handa S, Suzuki H, Harada H, Yamada S, et al: Establishment of CMab-43, a sensitive and specific Anti-CD133 monoclonal antibody, for immunohistochemistry. Monoclon Antib Immunodiagn Immunother 36: 231-235, 2017.

55. Kato Y, Ohishi T, Yamada S, Itai S, Furusawa Y, Sano M, Nakamura T, Kawada $M$ and Kaneko MK: Anti-CD133 Monoclonal Antibody CMab-43 exerts antitumor activity in a mouse xenograft model of colon cancer. Monoclon Antib Immunodiagn Immunother 38: 75-78, 2019.

56. Schoeberl B, Faber AC, Li D, Liang MC, Crosby K, Onsum M, Burenkova O, Pace E, Walton Z, Nie L, et al: An ErbB3 antibody, MM-121, is active in cancers with ligand-dependent activation. Cancer Res 70: 2485-2494, 2010.

57. Schoeberl B, Pace EA, Fitzgerald JB, Harms BD, Xu L, Nie L, Linggi B, Kalra A, Paragas V, Bukhalid R, et al: Therapeutically targeting ErbB3: A key node in ligand-induced activation of the ErbB receptor-PI3K axis. Sci Signal 2: ra31, 2009.

58. Furusawa Y, Yamada S, Itai S, Nakamura T, Yanaka M, Sano M, Harada H, Fukui M, Kaneko MK and Kato Y: PMab-219: A monoclonal antibody for the immunohistochemical analysis of horse podoplanin. Biochem Biophys Rep 18: 100616, 2019.

59. Furusawa Y, Kaneko MK, Nakamura T, Itai S, Fukui M, Harada H, Yamada S and Kato Y: Establishment of a monoclonal antibody PMab-231 for tiger podoplanin. Monoclon Antib Immunodiagn Immunother 38: 89-95, 2019.
60. Furusawa Y, Takei J, Sayama Y, Yamada S, Kaneko MK and Kato Y: Development of an anti-bear podoplanin monoclonal antibody PMab-247 for immunohistochemical analysis. Biochem Biophys Rep 18: 100644, 2019.

61. Furusawa Y, Yamada S, Itai S, Nakamura T, Takei J, Sano M, Harada H, Fukui M, Kaneko MK and Kato Y: Establishment of a monoclonal antibody PMab-233 for immunohistochemical analysis against Tasmanian devil podoplanin. Biochem Biophys Rep 18: 100631, 2019.

62. Furusawa Y, Kaneko MK and Kato Y: Establishment of $\mathrm{C}_{20}$ Mab-11, a novel anti-CD20 monoclonal antibody, for the detection of B cells. Oncol Lett 20: 1961-1967, 2020.

63. Yamada S, Itai S, Nakamura T, Yanaka M, Kaneko MK and Kato Y: Detection of high CD44 expression in oral cancers using the novel monoclonal antibody, $\mathrm{C}_{44} \mathrm{Mab}-5$. Biochem Biophys Rep 14: 64-68, 2018.

64. Sayama Y, Kaneko MK and Kato Y: Development and characterization of TrMab-6, a novel anti-TROP2 monoclonal antibody for antigen detection in breast cancer. Mol Med Rep 23: 92, 2021.

65. Sayama Y, Kaneko MK, Takei J, Hosono H, Sano M, Asano T and Kato Y: Establishment of a novel anti-TROP2 monoclonal antibody TrMab-29 for immunohistochemical analysis. Biochem Biophys Rep 25: 100902, 2021.

66. Kato Y and Kaneko MK: A cancer-specific monoclonal antibody recognizes the aberrantly glycosylated podoplanin. Sci Rep 4: 5924,2014

67. Wang Y, Yang H and Duan G: HER3 over-expression and overall survival in gastrointestinal cancers. Oncotarget 6: 42868-42878, 2015.

68. Stahler A, Heinemann V, Neumann J, Crispin A, Schalhorn A, Stintzing S, Giessen-Jung C, Fischer von Weikersthal L, Vehling-Kaiser U, Stauch M, et al: Prevalence and influence on outcome of HER2/neu, HER3 and NRG1 expression in patients with metastatic colorectal cancer. Anticancer Drugs 28: 717-722, 2017.

This work is licensed under a Creative Commons Attribution-NonCommercial-NoDerivatives 4.0 International (CC BY-NC-ND 4.0) License. 